Original Article Received/Accepted Dates

$06.12 .2021 / 20.02 .2021$

DOI 10.52096/usbd.6.24.2
International Journal of Social Sciences

Uluslararası Sosyal Bilimler Dergisi

www.sobider.net $\quad$ ISSN: 2548-0685

\title{
Mehmet Kavukçu ve Olafur Eliasson'un Eserlerinde Küresel Bir Sorun Olan Su
}

\author{
Doç. Dr. Gonca YAYAN
}

Gazi Üniversitesi

Eğitim Fakültesi

Güzel Sanatlar Eğitimi Bölümü

Resim - İş Eğitimi Ana Bilim Dalı gyayan@gazi.edu.tr, yayangonca@gmail.com

Orcid: 0000-0002-2915-3137

Yusuf HAN

Gazi Üniversitesi

Eğitim Fakültesi

Güzel Sanatlar Eğitimi Bölümü

Resim - İş Eğitimi Ana Bilim Dalı

ysfhan.503@gmail.com

Orcid:0000-0002-6944-9477

\section{Özet}

Dünya üzerinde bütün canlıların yaşamını sürdürebilmesi için iki temel unsur oksijen ve sudur. Su biyolojik yaşamın sürdürülebilmesini sağlayan temel bir unsur olarak tanımlanmaktadır. Su günümüzde özellikleri itibariyle yalnızca canlı çevre üzerine değil cansız çevre üzerine de oldukça etkili bir maddedir. Çünkü yaşam suyla başlamıştır. Günümüzde çok tartışılan konular içerisinde iklim değişikliliğin su kaynakları ve yeryüzündeki su miktarı üzerindekileri etkileri yer almaktadır. İklim krizi ve küresel ısınma sonucu su kaynaklarının azalması yer kürede yaşayan canlılar için önemli bir sorun teşkil etmeye de başlamıştır. İnsanoğlu bu problemi en kısa zamanda çözmek için harekete geçmesi gerektiğini bilmesine rağmen yeterince önlem almamaktadır. $\mathrm{Bu}$ yüzden 
dernekler, vakıflar ve duyarlık sahibi insanlar hatta sanatçılar yer kürede yaşayanları diğer insanları uyarmak ve bir farkındalık yaratmak çabası içine girmişlerdir. Bazı sanatçılar eserlerinde suyun toplumlar üzerindeki etkilerini örnek çalışmalarıyla göstermeyi amaçlarken kendi sanatsal üslupları ile de bunu dile getirmektedirler. Bu araştırmada nitel araştırma yöntemi ile iki sanatçının suyu konu alan eserleri hakkında literatür taraması yapılmış olup bu kapsamda Mehmet Kavukçu ve Olafur Eliasson'un eserleri incelenerek nasıl bir farkındalık yaratıkları ortaya koyulmuştur.

Anahtar Kelimeler: Küresel ısınma, su, Mehmet Kavukçu, Olafur Eliasson

\title{
Water as a Global Problem in the Works of Mehmet Kavukçu and Olafur Eliasson
}

\begin{abstract}
Oxygen and water are two basic elements for the survival of all living things on Earth. Water is defined as a basic element that ensures the sustainability of biological life. Today, water is a very effective substance not only on the living environment but also on the inanimate environment due to its properties. Because life began in water. Today the effects of climate change on water resources and the amount of water on earth are oxygen and water are. The reduction of water resources as a result of the climate crisis and global warming has also started to pose an important problem for the creatures living on the earth. Although human beings know that they need to take action to solve this problem as soon as possible, they do not take enough precautions. Therefore associations, foundations and sensitive people and even artists have made an effort to warn other people living on the planet and create an awareness. Some artists express this on their own artistic style while aiming to depict influences of water on societies with their sample artworks. In this research, qualitative research method, literature review about the works of two artists on water, and in this context, the works of Mehmet Kavukçu and Olafur Eliasson were examined and what kind of awareness creations were revealed.
\end{abstract}

Keywords: Global warming, water, Mehmet Kavukçu, Olafur Eliasson

\section{Giriş}

Yaşadığımız evrende hayatın vazgeçilmez en önemli unsuru olan su, insanların bilinçsiz kullanımı, küresel ısınma ve iklim değişikliğinin sonrasında su kaynaklarının azalmasına neden olmaktadır. 
$\mathrm{Bu}$ durum günümüzde azalan su kaynaklarının önemini gittikçe artırmaktadır. Çünkü kaynakların fiziksel olarak parçalanarak toprağın oluşması içindeki maddelerin çözünerek toprağın verimli hale gelmesi, bitkilerin ortaya çıkması, kökten dallardaki yapraklara kadar gerekli yapı taşlarının taşınması ve fotosentez gibi doğa olaylarının hepsi su sayesinde gerçekleşmektedir. Su günümüzde doğal kaynaklardan farklı olarak, ekonomik değerinin haricinde, günümüzde sosyal ve politik amaçlar doğrultusunda kullanılmaya müsait bir meta olarak da karşımıza çıkmaktadır. Su ile yer küremiz, son dönemlerinde iklim koşullarında meydana gelen düzensizlikler ile karşı karşıyadır. İklimlerde oluşan değişiklikler, insan hayatı üzerinde fark edilir etkilere de sebep olmaktadır. Bugün bilimin geldiği noktaya bakıldığında; iklim değiş̧ikliği nedeniyle buzulların erimesi, kuraklık, sel, gıda yetersizliği, biyolojik çeşitliliğin azalması, türlerin yok olması, kitlesel göçler ve sosyal patlamaların ortaya çıkması kaçınılmaz gibi görülmektedir. Artık dünyamız çevresel bozulma sonucunda kontrolsüz büyümenin ekolojik sınırlarla karşılaşacağı ve mevcut durumun sürdürülemez olduğu bir ütopya değildir (Luke, 1992). Dolayısı ile meydana gelen olumsuz etkiler, tarım ve orman alanlarıyla ürünlerinde azalışa neden olurken dünyanın gündeminede de önemini korumaya devam etmektedir. Çevre ile ilgili dengenin korunmasının yanında canlı yaşamının sürdürülebilmesi su ve su kaynakları, tarım orman arazileri ile ilgili önlemlerin alınması her duyarlı dünya vatandaşının göstermesi gereken bir zaruret olmaktadır (Karaman ve Gökalp, 2010: 59-60). Küresel ısınma ve iklim değişikliğinde bu mücadelenin kazanılması; öncelikle bireylerin, sonra da toplumların farkındalık düzeyinin artmasıyla doğru orantılıdır. Çünkü tüm doğal varlıklar kendi başlarına evrensel bir değere sahip oldukları için saygıyı hak etmektedirler (Barrow, 1997; Türe, 2010: 226).

Günümüzde küresel 1sınma ve iklim değişikliği kavramları aslında birbirlerinin yerine kullanılmaktadır. Fakat bu iki kavram farklı anlamlar taşımaktadır. Küresel ısınma dünyanın ortalama sıcaklığın iklim değiş̧ikliğine yol açacak olan artışı anlamına gelirken iklim değişikliği ise belirli bölgelerdeki mevsimsel sıcaklık, yağış ve nem değerlerindeki değişimler olarak tanımlanmaktadır (Selçuk,2009: 166).

Dünyada kullanılan tatlı suyun büyük bir bölümü ekosistemlerin devamlıllğı için çok önemli olurken kullanım alanlarına baktığımızda tarım, sanayi ve konutlar olmak üzere üç sektörde yer aldığ 1 görülmektedir. Bu sektörler arasında aslında önemli birde su rekabeti söz konusudur. Ancak ilerleyen zamanlarda tarıma düşen su kullanım payı gittikçe azalırken dünya nüfusunun giderek artması, sanayi ve konutlarda tüketilen tatı su payının bilinçsiz bir şekilde kullanıldığını da 
göstermektedir. Gittikçe artan bu küresel 1sınma sonucunda yapılan öngörülerde ise su kaynaklarının azalmasının orman yangınları, çölleşme ve çevreyle ilgili bozulmaları da beraberinde getirdiğine vurgu yapılmaktadır (Ateş, 2008, s.66).

Hatta bununla birlikte kentlerde su sıkıntılarının başlaması kaçınılmaz olurken suya olan gereksinimlerde hızlı artış gözlemlenmektedir. Mevsimsel kar yağışı ve karın kapladığı örtülerdeki azalmalar ise kış dönemlerinin kısalmalarına neden olmaktadır. Bu durum başta su kaynaklarının akabinde tarım, ulaştırma, enerji sektörlerinde de olumsuzluklara yol açmaktadır. Ayrıca küresel 1sınmayla buzulların erimesi deniz seviyesinin yükselmesi, iklimlerin kayması gibi değişikliklerini beraberinde getirmiştir (Karaman ve Gökalp, 2010: 61).

Dünyada meydana gelen bu olaylara sanatçılarda hiçbir zaman duyarsız kalmamışlardır. İlk çağlardan beri sanatçılar, çevreyle ilgili yaşadıklarını, duyularıyla elde ettiği bilgileri, yeni bakış açılarıyla yorumlayarak eserlerine aktaran insanlar olmuşlardır. Sanat yoluyla bu gerçeklikler betimlenip sergilenmiş, doğaya ait ilişkiler, estetik imgelerle anlatılmaya çalışılmış ve sanatçılarda doğaya ait gizleri izleyicisine sezdirerek beyinlerinde hiçbir işlem yapmadan doğrudan algılamalarını sağlamışlardır. Böylece insan sezginin önü açılarak düşünce ortamından elde edilen bilginin insanın içsel dünyasındaki seyahatinde klasik diyalektik mantık geçerliliğini yitirirken, günümüz bilim çevrelerince "fuzzylogic" olarak tanımlanan bir örtülü mantığın devreye sokulmasına da imkân verilmiştir (Türe, 2014: 227)

İşte günümüzde doğaya yönelik sanat, materyalist toplum mantığımızın mizacına ters gelen doğal değerlere yeniden yönelen ilgiyi besleyerek, bozulabilirken dünyanın dengeleri içindeki bitki, hayvan ve insanı kapsayan bir ekolojiyi de bizlere fark ettirerek çevre için saygıyı aşılamaya da yardımcı olabilmektedir. Böylece kentlerin herhangi bir yerinde sergilenen bir heykel, bir resim ya da bir grafik tasarımı bile, yaşamında hiçbir sanat galerisini gitmemiş olan insanlar üzerinde de yeni ve sağlıklı bir ilgi oluşturma işlevine sahip olabilmektedir (Karavit, 2008).

$\mathrm{Bu}$ itibarla günümüzde ortaya çıkan ekolojik sanat uygulamalarının temelinde de dünyanın ekolojik ve çevresel bütünselliğinin korunması algısı yatmaktadır. Sanatçının etkilendiği bu sürecin sonucunda ortaya çıan sanat eserleriyle de hem duygusal anlamda hem de zihinsel anlamda izleyicisini etkileyerek birçok konuda beklenen farkındalık oluşturula bilinmektedir (Harrison ve Harrison, 1993; Kagan ve Kirchberg, 2008). 
Gezegenimizi anlamamıza aracılık eden ekoloji gibi, ekolojik sanat olarak da tanımlayabileceğimiz çevresel sanatta da başlıca amaç; insanın çevresindeki organik yaşamla bütünleşmesidir (Türe,2014: 236)

Bununla birlikte beli bir mekânının özeliklerini kullanıp irdeleyen ve izleyici katılımının temel bir gereklilik olduğu, kapalı ve açık mekânlarda yapılan bir sanat türü olarak tanımlanmaktadır. Kökeni kavramsal sanatla ve 20.yy. başındaki Marcel Duchamp'ın hazır yapıtlarında ve Kurt Schwitters' kadar giden enstalasyonlar yanında çağdaş sanatta mimarlık ve performans dışında görsel sanat disiplinlerden de destek alarak oluşan hibrit bir tarz olarak gelişmiş ve 1970'lerden şekillenmeye de başlamıştır (https://tr.wikipedia.org). Diğer adıyla Enstalasyon ya da yerleştirme sanatı aslında bilinen geleneksel sanat ürünlerinden farklı olarak çevreden ayrı bir sanat nesnesi içermeyip belirli bir mekân içinde oluşturulmaktadır. Yapılan araştırmalar bir mesajın bilgiden çok estetiğe dayalı olarak sezi yoluyla algılanma hızının daha yüksek olduğunu ortaya koymaktadır (Gormley, 2010,). Doğası gereği mantık yolunu kullanan bilimsel bilginin iletimi sezgi iletimi kadar kolay ya da kendiliğinden olan bir eylem değildir (Karaçay, 2013).

Bugün dünyanın içinde bulunduğu problemleri duyarlılık sahibi olan insanlar ve özellikle de sanatçılar kendi üslupları ile bir farkındalık yaratma çabası içindedirler. Bu araştırma kapsamında küresel ısınma ve iklim krizinin etkilediği su kaynaklarının azalmasına performansları ile dikkat çeken Mehmet Kavukçu üç performans ve OlafurEliasson'nun suyu konu edinen altı enstalasyonu incelenmiştir. $\mathrm{Bu}$ araştırmada nitel araştırma yöntemlerinden doküman analizi (literatür taraması) ve betimsel eser analiz yöntemlerine başvurulmuştur. Doküman analizi, araştırılması amaçlanan olgu veya olgulara yönelik bilgilerin yer aldığı yazılı materyallerin analizini kapsar (Yıldırım ve Şimşek: 2018). Bu kapsamda, seçilen sanatçılar ve eserleri ile ilgili yazılan tez, makale, haber kaynakları, röportajlar incelenerek, araştırmanın amacına uygun doküman oluşturulmaya çalışılmıştır.

\section{Araştırmaya konu olan Mehmet Kavukçu}

Enstalasyon ya da yerleştirme sanatına eserlerinde ağırlık veren sanatçı Atatürk Üniversitesi Meslek Yüksek Okulu İnşaat Bölümünden mezun olduktan sonra 1987-1992 yılları arasında MSÜGSF Resim Bölümünden öğrenim görmüştür Adnan Çöker, Yusuf Taktak ve Mustafa Ata ile 
uygulamalı atölyelerinde Litografi ve fresk denemeleri yapmış ve bugün de Erzincan Üniversitesi Resim Bölümünde Prof. Dr. olarak görev yapmaktadır (http://www.turkishpaintings.com). Bu araştırmada Kavukçu'nun yerleştirme sanatı kapsamında insanlık ve şiddet temalı performansları incelenmiş̧tir.
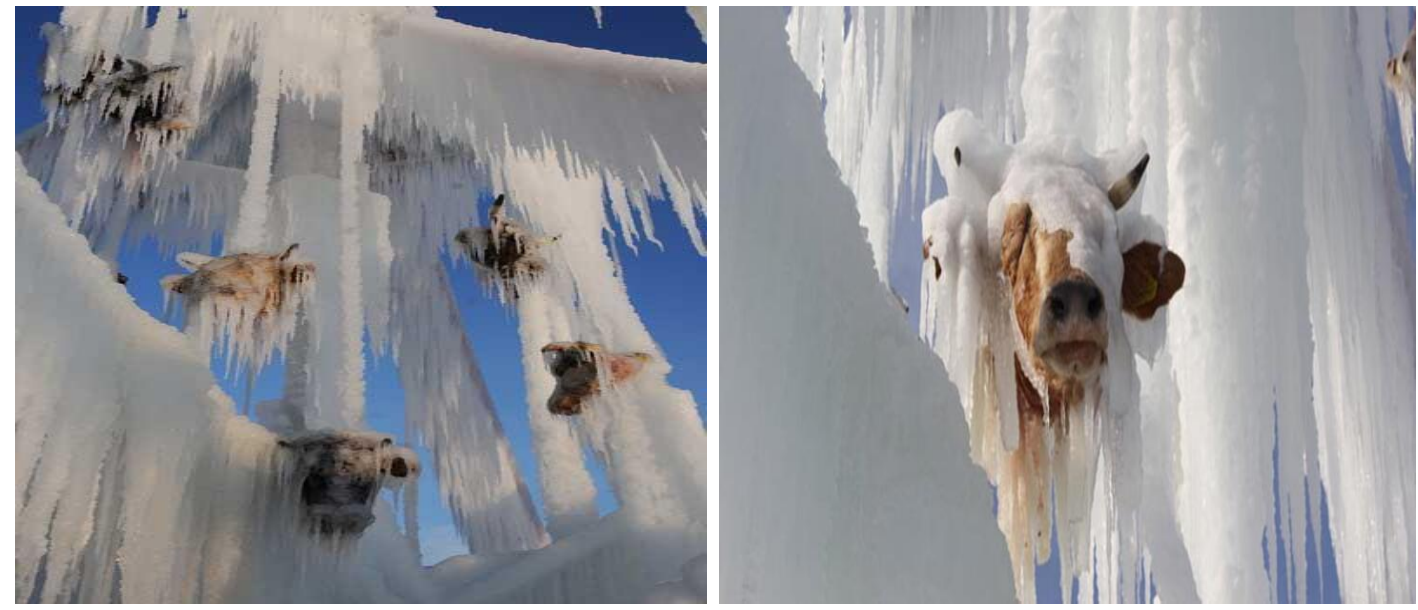

Görsel -1 2014, Erzurum, sanatçı soğuk bir havada ve şiddete dikkat çekmek için kombinadan aldığı öküz başlarıyla buzdan yararlanmıştır.

Sanatçı eseriyle ilgili olarak "Şiddet başlı̆̆ı altında yapmış olduğum alan kurgu çalışmasında yaşadığımız doğanın şartlarını suyla buluşturup, buza dönüşü̈rürken soğuğun şiddetini vurguladım. Öküz başları üzerinden, insana, hayvana ve doğaya yapılan şiddete bir gönderme yaparak tepkisel bir durumu sergilemek istedim. Türk kültüründe öküz, güç ve bereket sembolüdür. Bu çalı̧̧mayla aslında korkuyu ifade ederken insanın doğaya olan şiddetine dikkat çekmeğe çalışmıştır. Projenin yapılması yaklaşık bir hafta gece ve gündüz çalışarak yapılmıştır." (bir açılama da bulunmuştur. https://www.milliyet.com.tr/gundem/gorenleri-sasirtti-1825603,

Kavukçu'nun eserleri ile ilgili söylemleri göz önüne alındığında doğadaki şiddet kavramını su ile bağdaştırılırken, aslında insanların doğaya ve yer küreye yaptıkları şiddeti gözler önüne serilmektedir. (Görsel -1). 


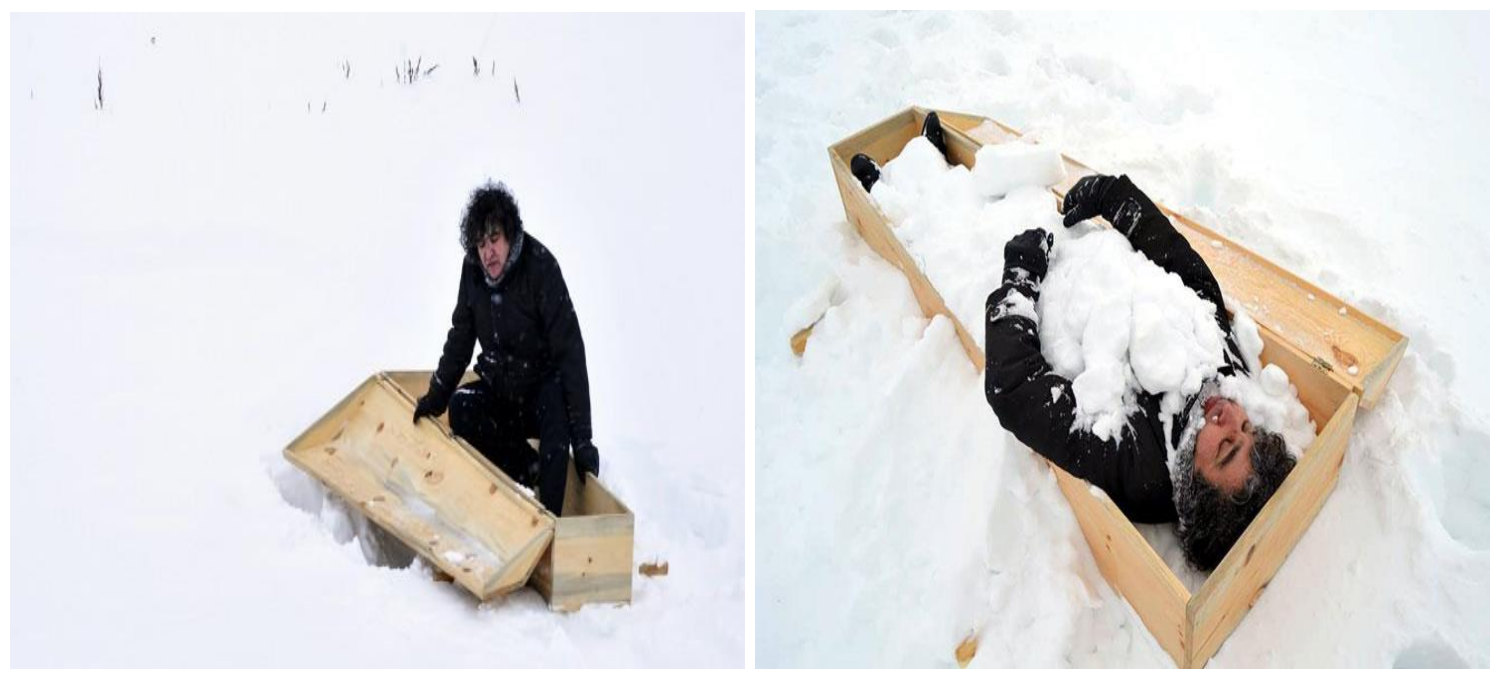

Görsel -2 Doğa, insan ve mekânda ölüm düşüncesi, 2019, Erzurum

Bu performansta (2019), mekânın ölüm düşüncesi ile örtüşen yönlerini, sanatın yol açıc1 ve umut verici oluşumu da ele alınmaktadır. Doğa ölümün anlatıldığı çalışmada aynı zamanda kontrast olarak doğanın korunması, beslenmesi, yenilenmesi ve şiddetli soğuktan etkilenip zarar görmeden bahara varabilmesinin de ifade edilmesi yanında kar ile sınırsız bir espas ilgisini de sanatçı kendi düşüncesinde ifade ederken insanın ölüm ve yaşam arasında ilişkisini de sorgulamıştır (http://www.dadasgazetesi.com)

Sanatçının bu eseri aynı zamanda küresel ısınma ve iklim değişikliğinin sonucu bozulan doğal dengenin etkilerini ölümle bağdaştırılmaya çalıştırılmıştır. İnsanlığının bu olanlara önlem almaması bu gidişata bir dur dememesi ve sorunun canlılar, yer küre insanlık için bir son vurgusu da yapılmak istenmiştir (Görsel -2). 

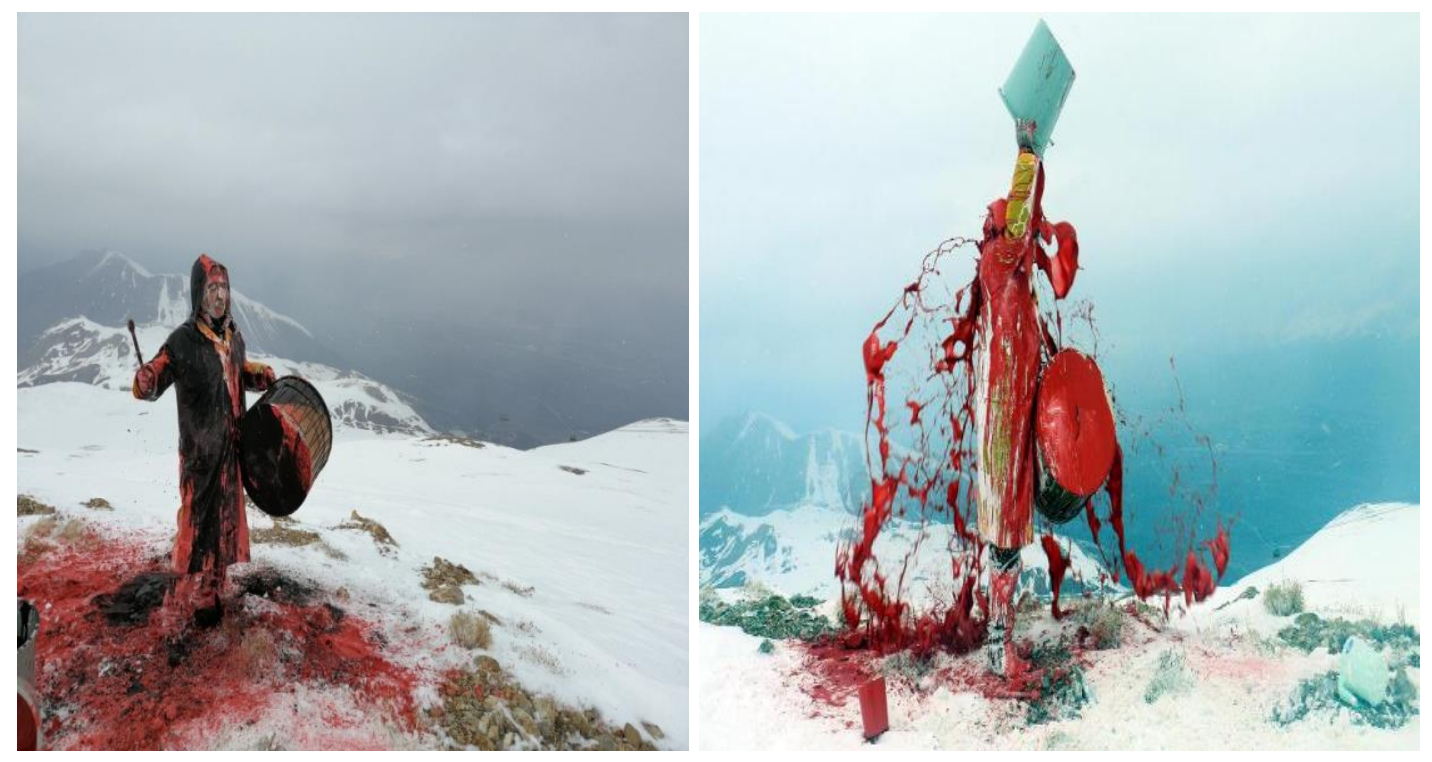

Görsel - 3 Doğada davulla dans, 2019, Ergan Dağı, Erzincan

Kavukçu bu performansla (2019) şiddet kavramına vurgu yapmaktadır. Sanatçı diğer performanslarında olduğu gibi, şiddeti kar ve buzullarla eşleştirmektedir. Bu performansında insanların doğaya olan tahribatına dikkatini çekmek için kanla ilişkilendirilen kırmızı boya ve davulu kullanmıştır. Bu çalışması ile sanatçı davulla telalık yapar gibi insanları uyarmaya çalışarak bir farkındalığı artırmaya gayret etmektedir (Görsel -3).

\section{Araştırmaya konu olan Olafur ELİASSON}

1967 yılında Kopenhang, Danimarka'da doğan sanatçı 1989- 1995 yılları arasında Danimarka Güzel Sanatlar Akademisi’nde eğitim görmüştür. Sanatçının kendi adını taşıyan atölyesinde yüzün üzerinde mimar, mühendis, usta uzman profesyoneller ve diğer sanatçılarla ile çalışmaktadır. Eliasson 2014 yılından bu yana Alle Güzel Sanatlar ve Tasarım Okulu'nda yardımcı profesör olarak görev yapmaktadır.

Sanatçı enstalasyon sanatı olarak eserlerin genellikle kapalı mekanlarda oluşturarak izleyiciye sunmayı tercih etmektedir. Eserlerinde objelerde uzay algısını, olmayacak şeyleri görmemizi sağlayacak şekilde değiştirmeyi amaçlamakta ve tek bir çalışma tarzına bağlı kalmaktadır. Eser 
üretme biçimi olarak da heykel, fotoğraf, film ve resimlerden faydalanmaktadır. Sanatın bir yol olduğu inanc1, düşünceyi eyleme dönüştürmek, onu sanat eserlerini yaratma niyeti ile yaratmaya iter ve insanları sivil konularda harekete geçirmeye teşvik etmektedir (French, 2011, s. 38).
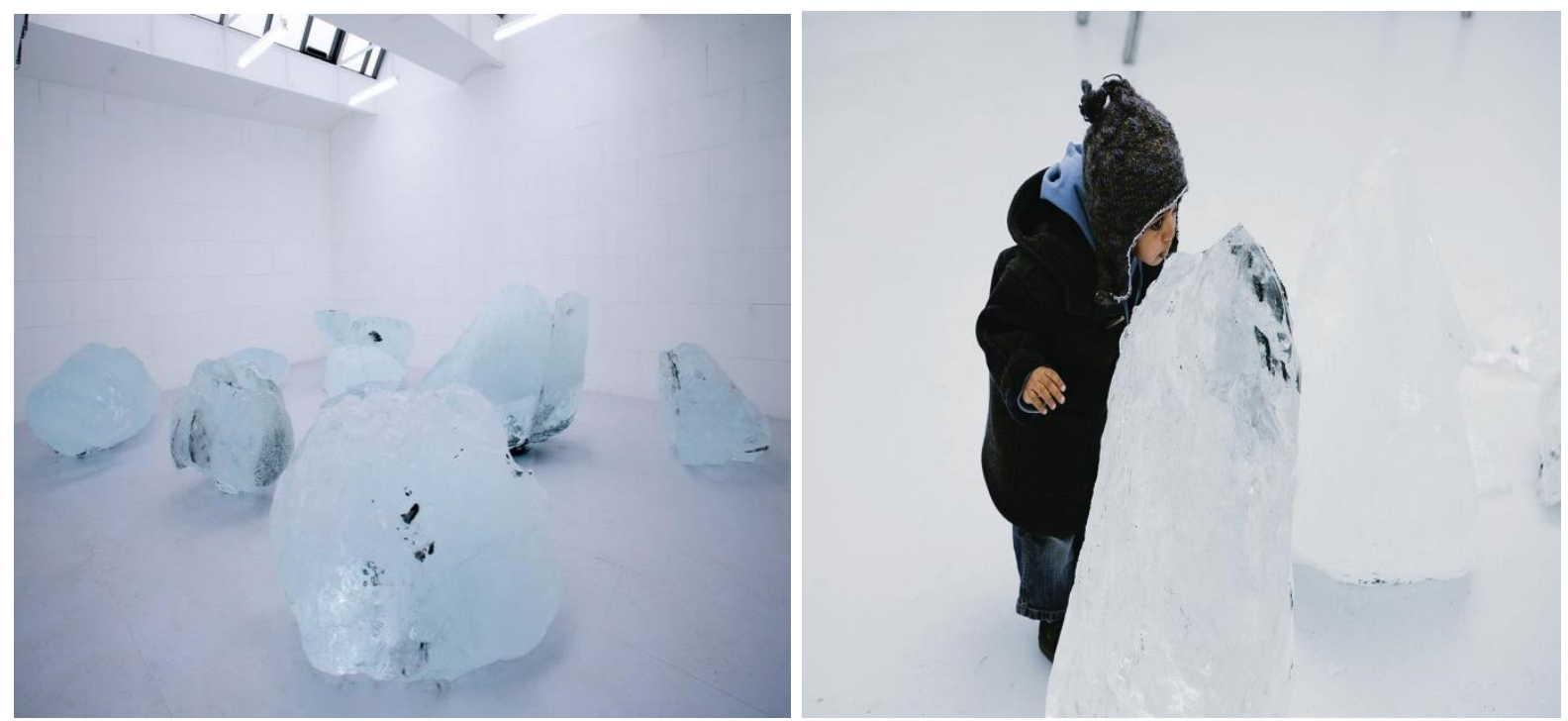

Görsel -4 Zaman Kaybınız (Your Waste of Time), Neugerriemschneider Berlin, 2006, (Fotoğraf: Jens Ziehe)

Your Waste of Time" için Eliasson, İzlanda'nın en büyük buzulu Vatnajökull'dan kopan buz parçalarını sergilemiştir. Güneş panelleriyle elde edilen güç aracıllğıyla soğutulan bir galeride sergilenen buz "heykeller", 800 yıllık dünyadaki varlığı boyunca, insanın fiziksel deneyimini bir perspektife koyarak sunmuştur. Ken Johnson, The New York Times'da 2013'teki haberinde Eliasson'un sergisinden alınan en büyük dersin "küresel 1sınmadan zarar gören doğa bizden intikamını alıyor" şeklinde ifade etmiş (https://gaiadergi.com). (Görsel -4) 


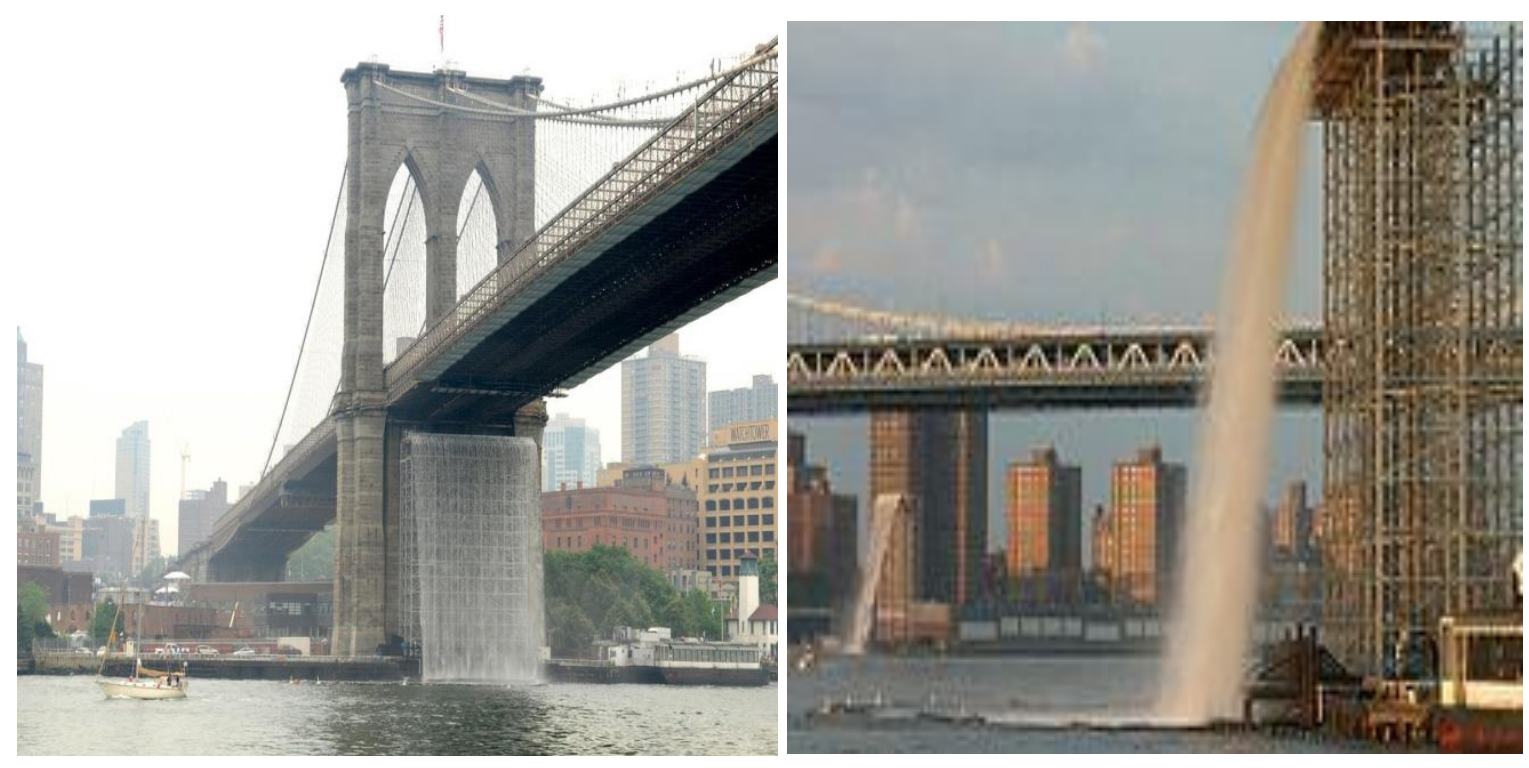

Görsel -5 Newyork City Waterfalls (Newyork Şehir Şelaleleri), Brooklyn Köprüsü Newyork, 2008 (Fotoğraf: Julienne Schaer)

Eliasson Public Art Fund tarafından New York limanında yüksekliği 90-120 ft (27-36 metre)arasında değişen “New York Şehir Şelaleleri” adı verilen dört insan yapımı şelaleyi yapmak için görevlendirilmiştir (https://en.wikipedia.org/wiki/Olafur_Eliasson).

Sanatçı bu eserleri ile izleyenlere hem görsel bir haz sağlamış hem de yer küremiz için önemli olan su kaynaklarından şelalelerin yapay halinin nasıl olacağına vurgu yapmıştır. Sanatçı yapay olanın hiçbir zaman orjinalin yerini tutamayacağını anlatırken de doğal su kaynaklarından olan şelalelerin ne nedenli önemli olduğu farkındalığını yaramayı amaçlamıştır (Görsel -5). 

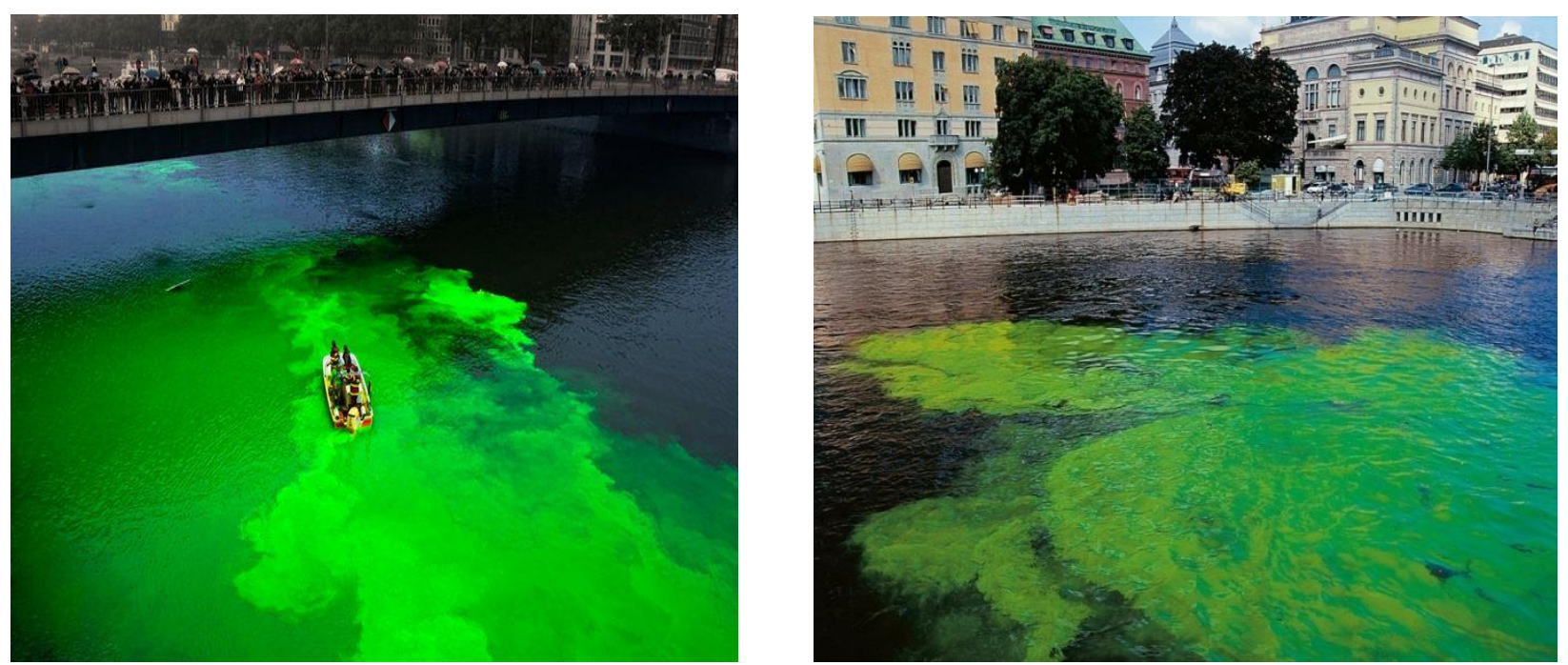

Görsel -6 Green River (Yeşil Nehir),

1998'de Eliasson, sıhhi tesisat sistemlerindeki sızıntıları izlemek için kullanılan, kolayca bulunabilen, toksik olmayan bir toz olan uranin'in, tüm nehirleri hastalıklı bir floresan yeşili boyayabileceğini keşfetmiştir. Eliasson, 1998 Berlin Bienali sırasında Spree Nehri'nde müze adası yakınlarındaki bir köprüden bir avuç toz saçarak bir test sürüşü gerçekleştirmiştir. Çevre açısından güvenli boyayı Moss Norveç (1998), Bremen (1998), Los Angeles (1999), Stockholm (2000) ve Tokyo'daki (2001) nehirlere her zaman önceden uyarıda bulunmadan sunmaya başlamıştır. İlk olarak Stockholm yayalarını şehrin suyunun kirli olduğu konusunda endişelendiren ile uluslararası üne kavuşmuştur. (https://en.wikipedia.org/wiki/Olafur_Eliasson)

Sanatçı bu eseri ile insanları hiç beklemedikleri bir anda suyun kirlenerek yok oluşuna vurgu yaparak onları bu doğa olayı ile karşı karşıya bırakmıştır (Görsel -6). Sanatçı bu durumla karşı karşıya kalan insanların verdikleri tepkilerle de farkındalık düzeylerini gözlemlemiştir. İnsanların farkında olması için yok oluşla bizzat karşı karşıya gelmesi gerektiğine vurgu yapmıştır. Sanatçının bu eseri ile bu hissi çok başarı bir şekilde gösterdiği de anlaşılmaktadır (Görsel -6). 

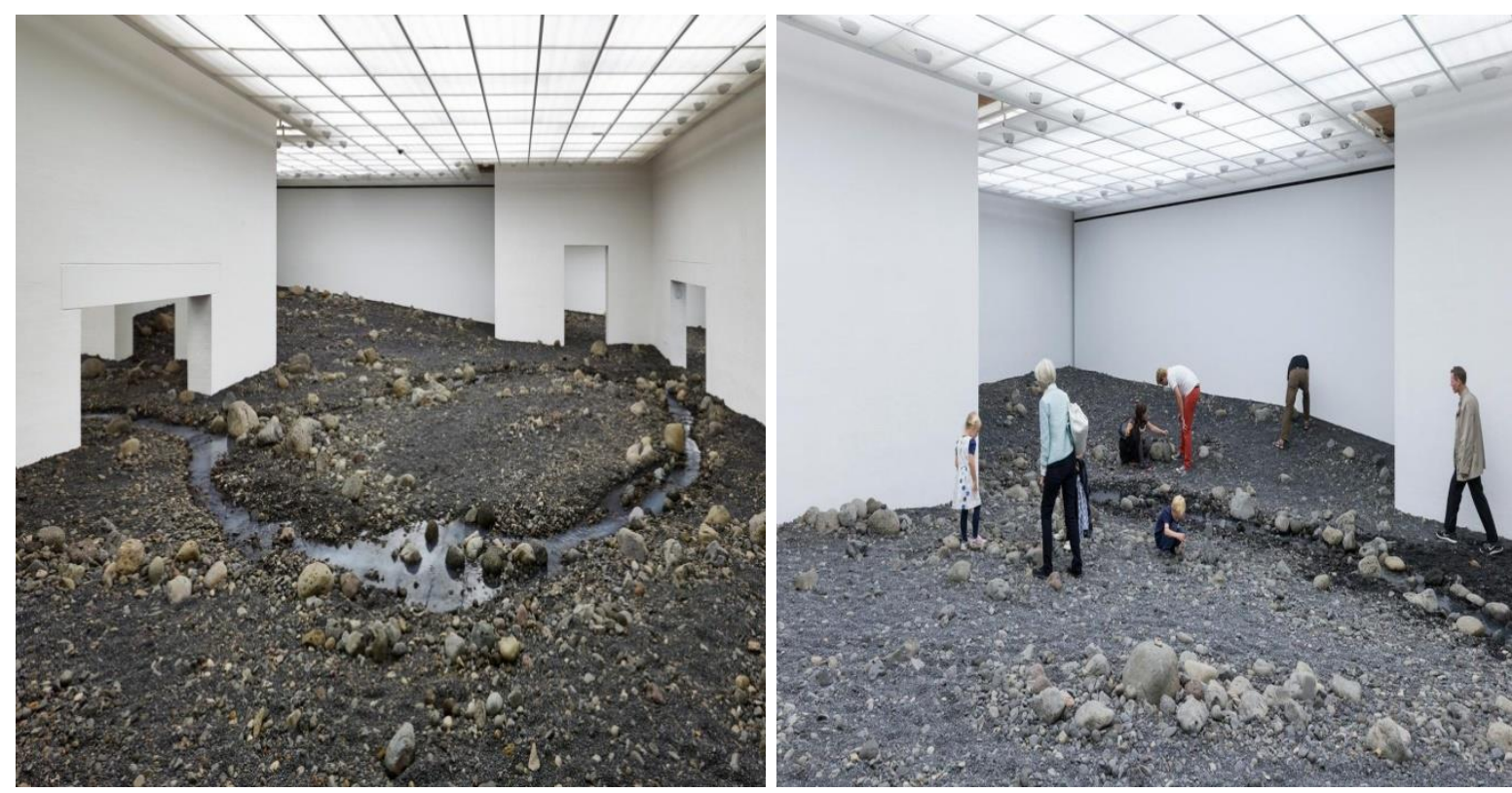

Görsel 7 Riverbed (Müze İçinde Nehir Yatağı), Louisiana Modern Sanat Müzesi, Humlebeak, Danimarka, 2014, (Fotoğraf: Iwan Baan)

Eliasson, bu eseirini 2014 y1lında Louisiana Modern Sanat Müzesi'nde oluşturmuştur. Bu eserle sanatçının vurguladığı herhangi bir bitki örtüsünden ve zıtlıklardan yoksun, tek düze akan suyu vurgu yapmıştır (Görsel-7). Eliasson'nun bu eseri müze ziyaretçilerini iç mekânda doğa ile etkileşimli bir deneyim sunmaktadır. Bu eser ile sanatçının neredeyse sosyal bir deney yarattığı görülmektedir. Böylece sanatçı farklı insanların farklı günlerde eserle olan etkileşimlerini gözlemleme ve tepkilerini değerlendirme firsatını da bulmuştur (https://bigumigu.com/haber/muzede-nehir-yatagi/). 

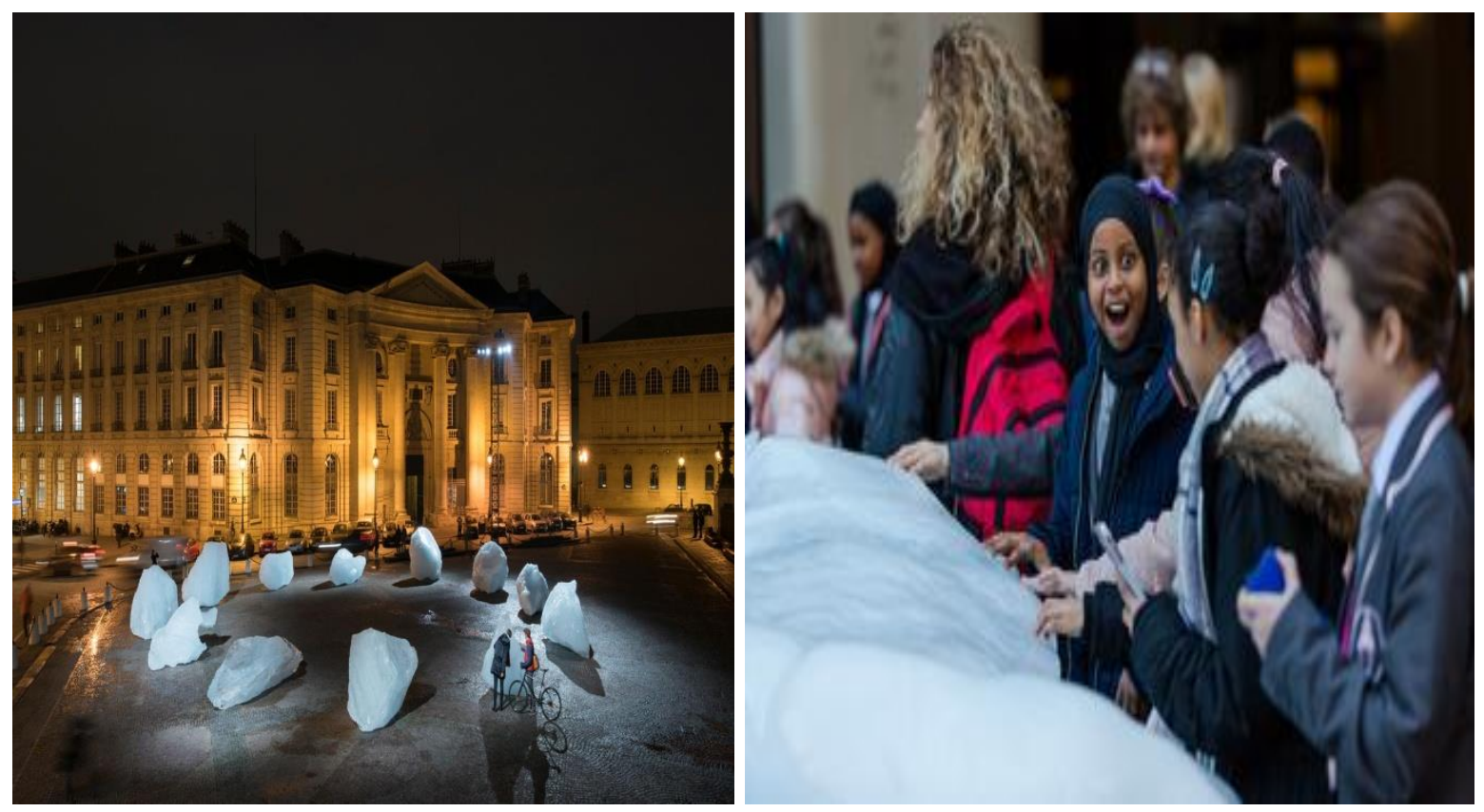

Görsel -8 Ice Watch (Buz Saati), 2014-2015

$\mathrm{Bu}$ eser günümüzün en önemli konularından biri olan iklim krizi ve küresel 1sınmadan dolay1 kutuplardaki buzulların erimesini gündeme getirmiştir. Eliasson'un diğer eserlerinde olduğu gibi insanları bu durumla direk olarak yüzleştirmektedir.

$\mathrm{Bu}$ eserin amacı kutuplardaki buzulun erime hızını gün 1şığına çıkarmıştır (Görsel -8). Yapılan araştırmalara buzulların erime hızının artığını küresel ısınma ile bu durumun devam etmesi durumunda kutuplardaki sıcaklığın 3 santigrat derece artacağını ifade etmişlerdir. Eliasson bu eseri Gröland'daki Nuuk Fiyordu'ndan her biri yaklaşık 11 ton ağırlığında denizden kopmuş 12 parça buzdan oluşturmuştur (Baldissarelli Bremm, 2019: 38-39).

Sanatçı buz kütlerini meydana saat şeklinde yerleştirerek zamana vurgu yapmış insanları eriyen bu buz kütleleri ile yüz yüze bırakmıştır. İnsanların bu erimekte olan buzullarla etkileşime geçmesi yüksek bir duyarlılı̆̆a neden olup oldukça ses getirmiştir (Görsel -8). 

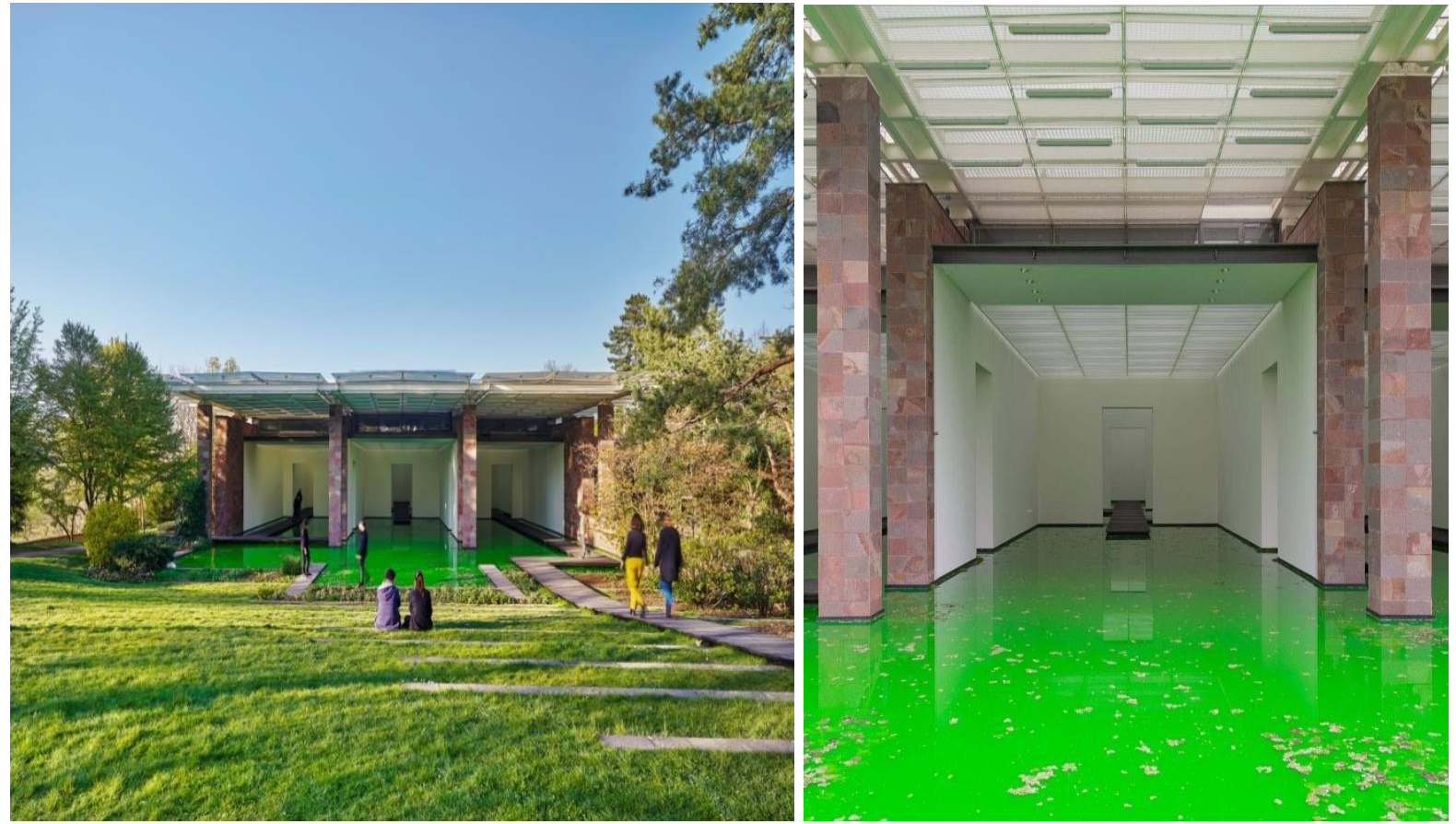

Görsel -9 Life (Yaşam), Fondation Beyeler Basel İsviçre, 2021 (Fotoğraf: Mark Niedermann)

Doğadaki "Yeşil Nehir" şovlanyla ilgi uyandıran sanatçı Olafur Eliasson, "Yaşam" (Life) adlı yeni sergisi için, İsviçre'de Basel şehri yakınlarındaki çağdaş sanat müzesi Fondation Beyeler'in içini ve çevresini yeşil suyla doldurmuştur. Danimarkalı- İzlandalı sanatçı Eliasson'un, peyzaj mimarı Günther Vogt ile iş birliğiyle gerçekleştirdiği bu sergi, ziyaretçilere yeni bir bakış açısı da sunmuştur. Bu iki sanatçı birlikte doğa ile kültür arasındaki bağları keşfeden birçok eser üretmiş ve izleyiciler doğal-kültürel bir manzara sunmuştur. Sanatçılar sergi için müzenin ön cam cephesi açılmış olup doğa müzeyi adeta ele geçirmiş gibi bir izlenim sunulmuştur. Mimar Renzo Piano tarafından tasarlanmış olan bu müzenin kapısı yoktur. 21 Nisan'da 2021 de ziyaretçilerle buluşan sergi, gece ve gündüz açık olup ziyaretçiler gelmediği zamanlaada kuşlar, böcekler, her tür canlı orada kendine bir yer bulabilmiştir.

Eliasson, tıpk1 1990'lı yıllardaki "Green River" (Yeşil Nehir) gösterilerindeki gibi, müzeye doldurduğu suyu floresanla yeşile boyamıştır. Günther Vogt, gölde yetişen su zambakları, kabuk çiçekleri ve başka tür bitkileri özenle seçerek suya yerleştirmiştir. Eliasson, su akıntılarının daha net görünmesi içinde "uranine" denilen, zararlı olmayan organik yeşil boyayla suyu 
renklendirmiştir. Doğayla kültürü buluşturmayı amaçlayan sanatçı, böylece ziyaretçilere müzenin içinde filizlenen bir "Hayat" 1 keşfettirmeye çalışılmıştır. Sanatçının sanat eserleri, baharla birlikte filizlenip, değişim, dönüşüm geçirirken ve aynı zamanda parlak yeşil suyun içinde derin bir heykel deneyimi de sunmuştur. Ziyaretçiler müzeye girdiklerinde, derinliği $80 \mathrm{~cm}$ 'yi bulan yeşil suyun üstündeki ahşap yürüyüş yolunda ilerleyerek, taze bitkileri keşfetmektedir (Görsel - 9). Bu süreç 2021 in temmuz ayına kadar sürerken, doğanın döngüsüne uygun olarak bitkilerle birlikte sergi de yok olmuştur. (https://www.alem.com.tr/sergiler/fondation-beyelerde-yesil-suda-yasam$\underline{1074523})$

\section{Sonuç}

Yer küremizin içinde bulunduğu küresel 1sınma ve iklim krizinin neden olduğu çölleşme ve su kaynaklarının azalması ile karşı karşıya olduğumuz bilinmektedir. İnsanlık olarak bu sorunu tersine çevirmek zorunda olduğumuz çevreci örgütler ve duyarlı insanlar tarafindan sıkça dile getirilmektedir. Ancak bakıldığından bu konu ile ilgili duyarsız insanların ve hükümetlerin duyarlı insanlar ve hükümetlere oranla fazla olması oldukça acıdır. Bütün dünya halklarının farkındalık düzeylerinin artması buna bağlı olarak da olaya müdahale etmesi gerektiğini bilmekteyiz. Geri dönüşümsüz bir hal aldığında şimdi yaşayacağımızı başka bir dünya olmadığını da unutmamamız gerekmektedir. Ayrıca unutmamız gereken bir şey daha varsa o da kendimizden sonraki nesillerimize bıkacağımız yegâne mirasın temiz, yeşil bir dünya olmasıdır. Bu durum göz önüne alındığında sanatçılara da oldukça çok iş düşmektedir. Biliyoruz ki sanatçılar gerek toplum içindeki rolleri, gerekse kendi üslupları ve farklı bakış açıları ile sergiledikleri eserler oldukça etkili olmaktadırlar. Bu araştırmada eserlerinde azalan su olgusuna yer veren Mehmet Kavukçu suyu buza dönüştürerek şiddetle bağdaştırmıştır. Sanatçı insanlığın hayvanlara, doğa, çevre ve yer küreye uyguladığı şiddeti buza dönüştürerek farkındalık sağlamaya çalışmıştır. Bu araştırmada eserlerinde azalan su olgusuna yer verirken Mehmet Kavukçu suyu buza dönüştürerek şiddetle bağdaştırmak istemiştir. İnsanlığın çevreye ve canlılara uygulanan şiddeti, yer küremizde tükenmeye başlamış olan su ve buzla dikkati çekerek bu olguların önemini de vurgulamıştır.

Ensatalsyon sanatçısı olan Olafur Eliasson ise eserleri ile insanların farkındalık düzeylerini artırmakla kalmayıp doğa ile bütünleştirmeyi amaçladığı görülmektedir. Bununla birlikte insanlara 
farklı bir deneyim imkânlarını da sunarken, her an gözümüzün önünde olanı, farklı bir açıdan bakmayı da sağlamaya çalışmıştır. Sanatçı su kaynakların her an tükenmesi ya da kirlene bileceği ve bununla yüz yüze kalacağımız vurgusunu çok başarı bir şekilde çalışmalarıyla da vurgulamıştır.

Küresel ısınma ve iklim krizi ve su kaynaklarının azalması sonucu olarak toplumlarda söz söyleyebilecek sanatçılar başta olmak üzere her insanın dile getirmesi gerektiği düşünülmektedir. Sanatçıların bu alanla ilgili daha fazla eser üretmesi gerekmektedir. Ancak böyle olursa insanlarda bir farkındalık sağlanabilir. Eğer bu başarılırsa üstümüze düşen görevi yerine getirmiş olup geleceğe güzel bir dünya mirası da bırakmış olabileceği düşünülmektedir.

\section{Kaynakça}

Ateş, İ., 2008, Küresel Isınmanın Sebep Olacağı Siyasal ve Ekonomik Gelişmeler ve Muhtemel Türkiye Yansımaları, Gebze Yüksek Teknoloji Enstitüsü Sosyal Bilimler Enstitüsü, Gebze.

Baldissarelli Bremm, A., 2019, Inhabiting the Environment through Art: the work of Dan Graham and Olafur Eliasson in Inhotim Institute as Instances of Environmental Aesthetics, Universiteit Leiden Master Programme Arts and Culture Specialization: Contemporary Art in a Global Perspective

Barrow C. J. (1997) EnvironmentalandSocialImpactAssessment: An Introduction, John Wiley and SonsInc., Switzerland. Birgün Gazetesi (2007).

French H. E., 2011, Sights of Desire Sites of Demise The Environment'in the Works of Edward Burtynsky and Olafur Eliasson, A thesis submitted to the Department of Art In conformity with the requirements for The degree of Master of Arts, Queen's University Kingston, Ontario, Canada

Gormley A. (2010). Art in the Time of Global Warming, LongHorizons: an Exploration of a Art + ClimateChange, British Consil, London, UK. 
Harrison, H. and Harrison M. N. (1993). "Positionstowardthe Earth: Art and EnvironmentalAwareness", Leonardo, (Art andSocialConsciousness: Special Issue): Vol. 26, No. 5.

Kagan, S. And Kirchberg V. (editors), (2008). Sustainability: a new frontierfort hearts and cultures, VerlagfurAkademischeSchriften, Frankfurt, Germany.

Karaçay T. (2014). Tilim ve http://www.baskent.edu.tr/ tkaracay/etudio/agora/sanat/BilimVe Sanat.htm

Karavit C. (2008). Doğadaki İz: Yeryüzü Sanatı, Telos Yayıncılık, İstanbul

Luke T. W. (1992). "Art and the Environmental Crisis: From Commodity Aestheticsto Ecology Aesthetics", Art Journal, Vol. 51, No. 2, Art andEcology,Summer.

Türe C. , (2010) Journalfor Nature Conservation 18 (4), 296-303,

Türe, C., 2014.Küresel iklim değişikliğinin toplumsal algısında görsel sanatların rolü sanat ve tasarım dergisi cilt 6 sayı 6

Türkeş, M., Sümer, U. M. ve Çetiner, G., 2000, Küresel iklim değişikliği ve olası etkileri, Çevre Bakanlığı, Birleşmiş Milletler İklim Değişikliği Çerçeve Sözleşmesi Seminer Notları (13 Nisan) İstanbul Sanayi Odası, 7-24, ÇKÖK Gn. Md., Ankara,

Selçuk, İ. Ş., 2009, Küresel Isınma, Türkiye'nin Enerji Güvenliği ve Geleceğe Yönelik Enerji Politikaları (Yüksek Lisans Tezi), A.Ü., SBE, İktisat ABD. Ankara

Karaman, S. Gökalp, Z. Küresel Isınma ve İklim Değişikliğinin Su Kaynakları Üzerine Etkileri, arım Bilimleri Araştırma Dergisi 3 (1): 59-66, 2010 ISSN: 1308-3945, E-ISSN: 1308-027X, www.nobel.gen.tr https://m.turkiyegazetesi.com.tr/gundem/447559.aspx 
http://cppenvstatic.s3.amazonaws.com/prod/s3fspublic/LA1111L_2018_Briggs_Artist Case Sudy 2A_Flores.pdf

https://tr.wikipedia.org/wiki/Yerle\%C5\%9Ftirme_sanat\%C4\%B1

https://worldwarzero.com/magazine/2021/06/life/

https://bigumigu.com/haber/muzede-nehir-yatagi

https://www.alem.com.tr/sergiler/fondation-beyelerde-yesil-suda-yasam-1074523

https://gaiadergi.com/iklim-degisikligini-korumayi-oncelikli-goren-17-yesil-sanatci/

https://www.uniqmagazine.com/tr/content-details/olafur-eliasson

https://olafureliasson.net/archive/artwork/WEK109190/ice-watch

https://www.uniqmagazine.com/tr/content-details/olafur-eliasson

https://s3euwest1.amazonaws.com/olafureliasson.net/objektimages_final/IMG_MDA115571_16

00px.jpg

http://clok.uclan.ac.uk/38172/1/ICE\%20FLOW.pdf

Yıldırım, A. ve Şimşek, H. (2018). Sosyal bilimlerde nitel araştırma yöntemleri (11. Baskı).

Ankara: Seçkin Yayıncılık. 